\title{
Social Support of Colleagues, Employee Loyalty, and Organizational Commitment in Microfinance Institutions: The Case of MFIS of the West Region of Cameroon
}

\author{
Douanla Jean $^{1} \&$ Nohotio Kenne Jean Mathurin ${ }^{1}$ \\ ${ }^{1}$ The Faculty of Economics and Management of the University of Dschang, Cameroon \\ Correspondence: Douanla Jean, The Faculty of Economics and Management of the University of Dschang. \\ Cameroon. E-mail: jcdouanla@yahoo.fr
}

Received: November 1, 2019

Accepted: December 8, 2019

Online Published: December 30, 2019

doi:10.5539/ijbm.v15n1p190

URL: https://doi.org/10.5539/ijbm.v15n1p190

\begin{abstract}
This study assesses the effects of the different dimensions of the social support of colleagues on the loyalty and commitment of micro finance personnel in the west region of Cameroon. We also examine the two-way relationship between organizational loyalty and commitment of the employees. To attain these objectives, we apply structural equations modeling to analyse data on 200 microfinance employees. The results obtained show that the loyalty of personnel to the organization is determined by the social emotional and professional support of colleagues. However, these variables do not explain the organizational commitment of these employees. We also find that in spite of the positive effect of loyalty on commitment, there is a negative effect on personnel loyalty in microfinance establishments. The latter finding is unexpected but can be explained by the specificities of the context or population of this study. We thus recommend that companies that wish to increase the level of commitment of their personnel to the organization should promote gregarious work.
\end{abstract}

Keywords: commitment, loyalty, emotional social support, professional social support

\section{Introduction}

The environment in which the companies evolve is turbulent and poses many challenges to these companies, one of which is finding and winning the loyalty of the best employees. The arrival on the labor market of the $\mathrm{Y}$ generation makes us believe that difficulties in the development of consumer loyalty are likely to increase (Giraud et al., 2012). This is also witnessed in the Cameroonian context given that according to the National Institute of Statistics (INS, 2011), only 7,5\% of employees wish to continue working in their current company. This general problem of the development of personnel loyalty in Cameroonian companies is exacerbated in MFEs (microfinance establishments) for various reasons: their low level of resources; poor working conditions, the violation of article 80 of the labour code limiting the number of working hours per week to 40 hours; the very competitive environment due to the presence of about 452 MFEs and many banks identified by the Ministry of Finance in 2012; the relatively low rate of labour contracts estimated at 20,3\% (INS, 2011), and the internationalization of the supply of jobs which facilitates the mobility of employees.

This situation predisposes the employees of Cameroonian MFEs to be unstable in the organization. The situation is even worse for companies in the West region of Cameroon where only $6,6 \%$ of employees wish to continue working for their present company (INS, 2011). According to Warnier (1993), the Bamilékés (people originating from the West region of Cameroon) change jobs several times during their career and each job is used as a springboard to reach the next. However, the loyalty of the personnel is of considerable importance to the organization. The study by Abderrahman and Bertrand (2019) shows that the quitting intentions of employees is negatively related to organizational performance.

In spite of this importance of the loyalty of the personnel to the company, all employees cannot be made loyal. Meyer and Allen (1991) share this point of view by stating that although personnel loyalty is an interesting criterion for the efficiency of the organization, it is insufficient. Concerning the issue of personnel loyalty, many authors hold that it should be accompanied by personnel commitment. This is the case of Thevenet et al., (2012) who hold that all administrators prefer committed collaborators and there exist situations where commitment is necessary since without it, efficiency cannot be achieved. Following this same reasoning, Colle (2006) states that: 
"beyond the need to preserve an employee in the company, the need to render him loyal stems from an increase in commitment". Cerdin and Peretti (2005) go further to consider commitment as one of the facets of personnel loyalty while Paille (2002) regards loyalty as a component of normative commitment. It is therefore not surprising that models of expected turnover integrate commitment. It is thus important to develop a loyal employee only if he is committed. This is why these two variables are integrated in the same model, although many researchers have done this before.

Bentein et al. (2005) and Stanley et al., (2013) simultaneously analyse loyalty and commitment. Like many former authors, they focus on showing that there exists a relationship between organizational commitment and the intention to leave the company. Very few studies like that of Paille (2004) include these variables in the same model as dependent variables. However, it is possible that a variable determines the loyalty of the personnel to the company while reducing their level of commitment, thus showing the relevance of the approach we adopt in this study. However, there are many factors that can be used to render personnel loyal and committed to the company.

The choice of the social support is justified by the predicted effects of trade theory and specifically Perceived Organizational Support or POS (Eisenberger, Huntington, Hutchison, and Sowa, 1986) and the TEAM Member Exchange or TME (Seers, 1989). These theories predict positive effects on the company based on the principle of reciprocity due to their contribution to the satisfaction and wellbeing of workers (Mellor and Collange, 2018), their positive effects on affective engagement (Kapela and Pohl, 2017), and corporate citizenship behaviour (Kapela and Pohl, 2019). These studies show that as predicted by POS and TME, this induces a positive reaction from the recipient. This can also result in the loyalty or commitment of the employee to the company.

Although many studies have examined the effects of the social support on the commitment and intention to leave (Reid et al., 2008; Simons and Jankowski, 2008), these studies approach social support from the source and not for the nature, or from its source and nature which is the ideal approach. Furthermore, research on social support is mostly on that of the hierarchy and not of colleagues as in this study. This choice is not baseless but is justified by the fact that they are frequently in contact with the employees and are more likely to give them a daily social support. Also, by referring to the TME (Seers, 1989), the social support of the colleagues is unique and likely to have characteristics which are interesting to examine. We therefore attach much interest to the social emotional and professional support, particularly that of colleagues.

The main contribution of this study is empirical because we seek to test our hypotheses in the context of Cameroonian microfinance employees. Specifically, we highlight the characteristics of the nature of the social support of colleagues on loyalty and organizational commitment. Also, the relationship between loyalty and commitment are analysed in a bi-directional manner. At the level of the methodology, the main contribution is that we use a multidimensional approach which enables us to explain several aspects of the studied phenomenon in the same model through structural equations.

To achieve the objectives mentioned above, this study is organized in three parts. We first present the theoretical framework of the study. The second part presents the methodology, while the results and their discussions are presented in the third part of the study.

\section{Material Studied}

We first clarify the concepts of the study, followed by the literature on the relationship between loyalty and commitment as well as their common determinants. We conclude this section by presenting the hypotheses of the study.

\subsection{Clarification of Concepts}

We present the controversies surrounding the concepts of loyalty, organizational commitment and the social support at work.

\subsubsection{Controversies Surrounding the Concept of Loyalty}

Peretti (2001) defines the loyal employee as one that has worked for long in the company, has a very low propensity to seek and examine external job offers, and generally has a strong feeling of belonging. According to Dutot (2004), the loyalty of the employee to the company corresponds to the development of trust between the employee and his organization and which is expressed by resistance to the adoption of an opportunistic behavior relative to external job offers. This definition reduces loyalty to a relationship of trust. However, there are many employees who remain in the company in spite of the absence of this relationship of trust. Moreover, in the transactional approach, what is important is not the relationship of trust, but productivity via the loyalty of the employee. This brings Paille (2004) to declare that a faithful employee has a long experience in the company, has 
no interest in external professional opportunities, and in his working environment, adopts a policy that privileges uninterrupted efforts and avoids voluntary actions that are likely to disrupt the operation of the organization.

\subsubsection{Organizational Commitment: Attitudinal and Behavioural Approaches}

In the transactional or behavioural approach, commitment is viewed within a logic of exchange (investment and remuneration) with expectations by the worker and the organization (Thevenet, 1993). It is thus observable through actions that are useful to the organization (Allen \& Meyer, 1990). The attitudinal approach is characterised by a strong belief in the goals and values of the organisation, a desire to make significant efforts to the profit of this organization, and a desire to remain a member (Mowday et al., 1982). According to Thevenet (1993), being committed is accepting a psychological contract according to which it is considered that the employee's own success is related to that of the company. In this vision, commitment refers to a mental construct that is not observable. For this purpose, certain authors (Mowday et al., 1982; Meyer \& Allen, 1997) militate for a complementarity of attitudinal and behavioral approaches. This is only possible in theory since no present day measurement scale covers these two aspects.

\subsubsection{Social Support at Work}

Social support at work can be defined as the set of actions of others which are useful or seek to be useful to someone who needs assistance (Deelstra et al., 2003). It is characterised by the intensity and nature of relations created, developed, and maintained between various individuals. This social support is frequently approached from the angle of the Perceived Organizational Support (POS) which refers to the beliefs of an employee on the extent to which the organisation takes into account his wellbeing and appreciates his contribution (Eisenberger et al., 1986). In other words, it is the perception the employee has of the commitment of the organisation towards him, based on the beliefs of the employee on the manner in which the organisation values his contribution and is interested in his wellbeing (Eisenberger et al., 1986). However, it should be recalled that this social support can come from the hierarchy or colleagues, and is made up of social emotional and social professional aspects. The emotional aspect refers to sympathy, care, love and comfort from which an employee benefits while the professional aspect refers to the assistance from which he benefits in carrying out or improving the tasks given him.

\subsection{Loyalty and Commitment to the Company: A Controversial Relationship}

It has been shown that emotional and normative commitments have a negative relationship with the employee turnover and the desire to leave the company (Meyer et al., 1993; Bentein et al., 2005). However, the relationship with measured commitment is far from being unanimous since Betein et al., (2005) show the existence of a negative and significant correlation between the desire to leave and the personnel turnover. On the other hand, many authors (O'Reilly \& Chatman, 1986; Meyer et al., 1993) obtain results that show that rather there exists a positive and significant correlation between these variables. However, the meta-analysis results of Mathieu and Zajac (1990) show that the correlation between organizational commitment and its main outcome (turnover) is only $-0,28$. Ten years afterwards, this weak correlation is confirmed by the meta-analysis of Griffeth et al., (2000), thus showing a controversial relationship between commitment and loyalty.

\subsection{Loyalty and Organizational Commitment: Two Variables with the Same Determinants}

The analysis of the common determinants of loyalty and organizational commitment can be done following many approaches.

Following the monetary approach, it is shown that the less well paid a worker is in a company, the more he is inclined to leave it (Edwin, 2005) and is thus less committed (Tremblay et al., 2000). However, it should be recalled that an employee-company relationship based on remuneration is likely to reduce the love of duty. This is also the case with the ownership of stocks by employees. Thus stock options, though qualified by some as golden cuffs, encourage employees to remain in the company if they are accompanied by a monetary reward (Klein, 1987). On the other hand, when these stocks are accompanied by participation in decision making, they bring the employee to be committed in the organization (Hammer \& Stern, 1980).

Concerning the personal characteristics of the employees, Mobley et al., (1979) despite not taking into account the specificities of each job show that the oldest employees are less inclined to leave the company whereas young people are very mobile and have less difficulties in finding a new job. Many other studies show the existence of a positive correlation between age, seniority and emotional commitment (Mathieu and Zajac, 1990; Mowdays et al.,1982). On the other hand, according to Peyrat-Guillard (2002), a young employee with little seniority is much more committed. There also exists a disagreement on the gender approach. Hom et al., (2008) show that women are more likely to leave their jobs than the men because of precariousness while Moyniham 
and Landuit (2008) show that women, because of their desire to serve the community, have lower rates of departure than men. Concerning commitment, it is shown that women are less committed than men given that working is not their only reason to live (Burke, 1999). In the same line of reasoning, commitment to the job is lower for women, relative to men (Cox and Nkomo, 1991). We however believe that these results would be more revealing if the studies take into account the degree of glass ceiling which reigns in the different sectors.

Concerning the status of the job, it is shown that part-time employees have higher levels of intention to leave and disengagement than full-time ones (Martin and Hafer, 1995). This can be attributed to the level of integration and the theory of equity. The views on commitment are far from being unanimous since Sinclair et al., (1999) show that part-time employees are more committed than the full-time ones because they benefit from more advantageous working conditions. On the other hand, McGinnis and Morrow (1990) show that there is no difference in the level of commitment depending on whether the job is full or part-time. It is thus necessary to continue research on this issue by using control variables.

Concerning the organization of work, Griffeth et al., (2000) reiterate a well-known result in the literature according to which: voluntary turnover is positively related to role conflicts. However, Netermeyer et al., (1995) show the absence of a relationship between the intention to leave the company and role conflicts. This ambiguity of roles is at the origin of the reduction of organizational commitment (Grima, 2004). Despite the fact that this relationship is disputed by many authors (Boshoff and Mels, 1995), some authors like Perrot (1999) suggest going further into the studies by distinguishing the different stages of role conflicts and ambiguity. Moreover, it is convenient to go beyond this and take into account the different dimensions of organizational commitment.

Concerning the development of competences, training is one of the human resource management practices identified to affect voluntary departures (Hortwitz et al., 2003). Moreover, certain employees hold that the training offered to them by the company is an opportunity for promotion (Marriot, 2001), and such a practice increases their desire to remain in the organisation (Cowan et al., 2002). The opportunities for training and development of competences are positively related to commitment (Tremblay et al., 2000). However, it is important to note the importance of employee participation in the definition of the contents of the training and planning.

Many other studies identify other common determinants of loyalty and commitment. We thus formulate the following hypotheses.

\subsection{Formulation of Hypotheses}

Many studies show that POS is positively related to organizational commitment (Meyer et al., 2002) but negatively related to the intention to leave (Perryer et al., 2010). Using an intermediation approach, Masterson et al., (2000) find that the effects of procedural justice on job satisfaction, organizational commitment, the intention to leave and CCO are determined by the POS. POS is globally related to the satisfaction of needs (Waistcoat et al., 2016) and negatively related to the intention to leave the organisation (Cropanzano et al., 1997). It takes the form of many other positive attitudes towards the company (Chen et al., 2005), and in a general manner, adhesion to the organizational goals and values (Fabre and Roussel, 2013). It is thus necessary to go beyond POS to explore the effects of the nature of this social support on loyalty and commitment in line with TME. We thus formulate the following hypotheses:

H1: The loyalty of the personnel to the company is positively affected by the social emotional support (H1a) and the social professional support $(\mathrm{H} 1 \mathrm{~b})$ of the colleagues.

$\mathrm{H} 2$ : Organizational commitment is determined by the social emotional support $(\mathrm{H} 2 \mathrm{a})$ and social professional support $(\mathrm{H} 2 \mathrm{~b})$ of the colleagues.

Commitment appears in the literature as one of the variables that precedes the loyalty of the personnel to the company. According to Mowday et al., (1979), committed individuals strongly adhere to the objectives and values of the organisation and wish to remain there. This idea is supported by Allen and Meyer (1996) for who commitment makes the voluntary departure of an employee of the organization less probable. Also, committed employees would be less often absent and more faithful to their company (Mathieu and Zajac, 1990). Meyer et al., (2002) also show that all the three dimensions of commitment are negatively related to the intention to leave. Moreover, many other studies show the existence of a correlation between commitment and loyalty (Mahieu and Zajac, 1990; Griffeth et al., 2000). We thus hypothesize the existence of a bidirectional relationship according to which:

H3: The commitment of the personnel to the company positively affects their loyalty to this company.

H4: The loyalty of the personnel to the company positively affects their organizational commitment 
The above hypotheses are summarized in the model below.

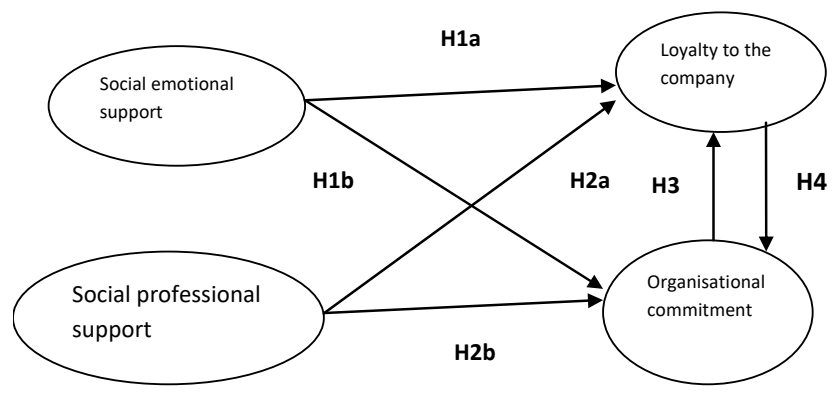

Figure 1.The research model

\section{Methodology}

In this section, we present the sample, the instruments used to measure the variables, the factorial analyzes and the validity of constructs, and the methods used the test the hypotheses.

\subsection{Study Population, Sample and Measurement of the Variables}

The study population consists of all the employees of the 38 agencies of microfinance establishments in 08 divisions of the west region of Cameroon. The sample used results from a simple random sampling of 200 employees of these MFEs. A questionnaire whose responses are those of the five class LIKERT scale is administered directly. The rate of response is $89,6 \%$ and consists of an equal number of men and women. $83 \%$ of the respondents are from the West region of Cameroon and reflect the fact that the MFIs mainly recruit the personnel originating from the place of localisation of the agencies concerned as recommended by MEDA (2007). This makes it possible to mitigate language problems and bring the customers to feel at ease from a psychosocial point of view.

The measurement of the social support is done using an international tool which is the questionnaire by Karasek and Theorell (1990). This questionnaire takes into account the social emotional and social professional support. In this study commitment is captured using the scale of Allen and Meyer (1990) while loyalty is measured in a subjective manner (intention to remain) using the scale of Wayne et al., (1997) in which the word work is replaced by "MFE". Loyalty is measured following the subjective dimension (rooting in the company). We use Peretti (2001) to take into account seniority (Note 1). Besides, this variable appears to be the best indicator of the loyalty of the personnel at the end of their career. The item "I have a significant experience (more than 8 years) in my MFI" is used, to which we add another item (Note 2): "I am willing to sign or accept a permanent contract with my MFI".

\subsection{Factorial Analysis, Validity of Construct and Method of Testing the Hypotheses}

It arises from the Exploratory Factor Analyzes (EFA) with varimax rotation, a one-dimensional structure of loyalty (intention to remain) whose explained variance is $55,67 \%$; a two-dimensional structure of social support (social emotional and social professional support) having an explained variance of $49,44 \%$ and a two-dimensional structure of organizational commitment (normative commitment and calculated commitment under dimension of perceived sacrifices) whose explained variance is $49,10 \%$. The internal validity of these factorial structures is evaluated by Joreskog's Rho coefficient for social emotional support $(0,810)$, social professional support $(0,857)$, loyalty $(0,813)$, normative commitment $(0,778)$ and calculated commitment from the dimension of perceived sacrifices $(0,684)$. The interpretation of the Confirmatory Factor analyzes is done using various indices $\left(\mathrm{X}^{2}, \mathrm{X}^{2 / d \mathrm{dl}}\right.$, AIC whose values must be the smallest possible; RMSEA which must be lower than 0,08 and ideally 0,05 ; the AGFI, CFI and the NNFI which must be higher than 0,90 ). The models resulting from the EFA are those which are better adjusted to the empirical data as shown by the different indices of adjustment in the table below. 
Table 1. Results of the confirmatory factorial analysis

\begin{tabular}{|c|c|c|c|c|c|c|c|c|}
\hline \multirow{2}{*}{ Variables } & \multirow{2}{*}{ Compared models } & \multicolumn{2}{|c|}{ Indices of parsimony } & \multicolumn{2}{|c|}{ Incremental indices } & \multicolumn{2}{|c|}{ Absolute indices } & \multirow[b]{2}{*}{ RMSEA } \\
\hline & & $X^{2 / d d l}$ & AIC & NNFI & CFI & $\mathrm{X}^{2}$ & AGFI & \\
\hline \multirow[t]{2}{*}{ Social support } & $\begin{array}{l}\text { Model with } 2 \text { factors resulting } \\
\text { from the EFA }\end{array}$ & 2,138 & 30,554 & 0,858 & 0,943 & 8,554 & 0,984 & 0,076 \\
\hline & One dimensional model & 4,311 & 41,553 & 0,587 & 0,794 & 21,553 & 0,874 & 0,129 \\
\hline \multirow{3}{*}{$\begin{array}{l}\text { Loyalty to the } \\
\text { company }\end{array}$} & $\begin{array}{l}\text { Model with } 1 \text { factor resulting } \\
\text { from the EFA }\end{array}$ & 0,135 & 16,271 & 1,033 & 1,000 & 0,271 & 0,997 & 0,000 \\
\hline & Dimensional plain model & 0,723 & 23,615 & 1,015 & 1,000 & 3,615 & 0,979 & 0,000 \\
\hline & $\begin{array}{l}\text { Model with } 2 \text { factors resulting } \\
\text { from the EFA }\end{array}$ & 0,593 & 30,740 & 1,090 & 1,000 & 4,740 & 0,980 & 0,000 \\
\hline Organizationa & One dimensional model & 2,246 & 375,145 & 0,652 & 0,693 & 303,145 & 0,788 & 0,079 \\
\hline \multirow[t]{2}{*}{ I commitment } & Model with 3 factors & 1,979 & 339,165 & 0,726 & 0,764 & 261,165 & 0,827 & 0,070 \\
\hline & Model with 4 factors & 1,940 & 334,292 & 0,737 & 0,778 & 250,292 & 0,827 & 0,069 \\
\hline
\end{tabular}

The dimensions of social support are clearly distinguished. All the factorial contributions relative to each sub-dimensions are significant at the $5 \%$ level. Moreover, the coefficients of convergent validity are 0,540 and 0,588 respectively for the social emotional and social professional aspects. The discriminating validity is evaluated by the approach of Hulland (1999). We note that each coefficient of convergent validity of dimensions of the social support is higher than the square of the correlation which exists between them $(0,092=0,0081)$, which shows the existence of a discriminating validity for each one of the sub-dimensions. It is however not the case with commitment given that all the factorial contributions are significant to $5 \%$, the coefficients of convergent validity are low and respectively of 0,234 and 0,236 for the normative commitment and calculated commitment. The discriminating validity also poses a problem because the coefficients of convergent validity are not higher than the square of the correlation which exist between the sub-dimensions of commitment $(0,4902=$ 0,2401). Taking this into account, commitment is used in the rest of the analysis in a uni-dimensional approach given that its Joreskog Rho is 0,623 .

To test the hypotheses, we use the method of structural equations which enables us to test a network of relationships simultaneously. The estimation of the structural model is done using the method of maximum likelihood. Besides, this is proposed by default in data analysis softwares and is the most used presently.

\section{Results and Discussion}

We respectively present the descriptive statistics and correlations between the different variables, the adjustment of the models, as well as the estimated parameters.

\subsection{Descriptive Statistics and Correlations between the Variables of the Study}

Table 2. Means, standard deviations and correlations between the variables

\begin{tabular}{llllllll}
\hline & Variables & M & ET & 1 & 2 & 3 & 4 \\
\hline 1 & Social emotional support & 3,235 & 1,074 & 1 & & & \\
2 & Social professional support & 3,623 & 1,134 & 0,09 & 1 & & \\
3 & Loyalty & 2,365 & 1,075 & $0,386^{* *}$ & $0,288^{* *}$ & 1 \\
4 & Commitment & 3,264 & 1,162 & 0,195 & 0,64 & $0,242^{* *}$ & 1 \\
\hline
\end{tabular}

** significant $=$ correlation.

It arises from this table that three correlations are significant, particularly the relationship (correlation) between each dimension of decisional freedom and loyalty (intention to remain), then the relationship between the loyalty and organizational commitment. It is however difficult to deduce the interaction between commitment and the intention to remain giving rise to the need to estimate the structural model.

\subsection{Evaluation of the Adjustment of the Model and Estimation of the Parameters}

The model tested is adjusted well to the empirical data since we obtain the following indices: GFI $=0,905$; RMSEA $=0,077 ;$ CFI $=0,988 ; X^{2 / d d l}=2,183 ; X^{2}=165,888 ; \rho<0,000$. The results of the hypothesis tests are presented in the figure below. 


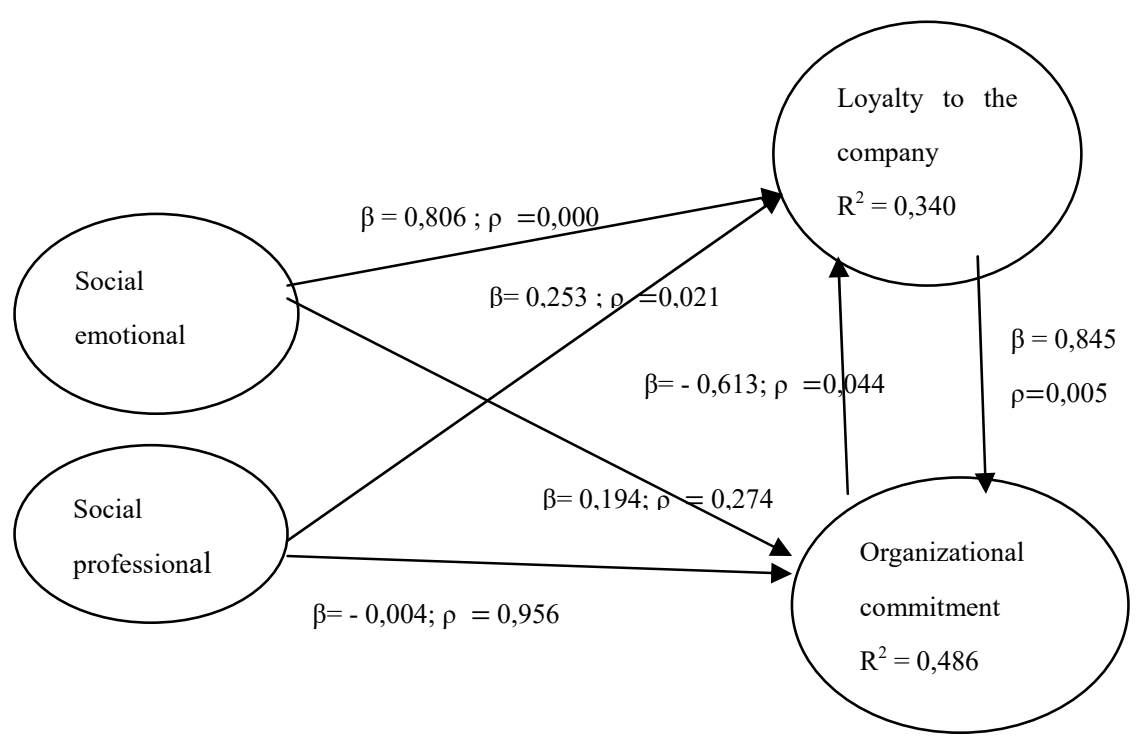

Figure 2. Results of causality analysis

\subsection{Interpretation and Discussions of Results}

4.3.1 The Loyalty to the Company: A Result of Social Emotional and Social Professional Support (H1) of the Colleagues

The first hypothesis (H1) is entirely accepted.In fact, we find from the empirical analysis that the social emotional support $(\beta=0,806 ; \rho<0,01)$ and social professional support $(\beta=0,253 ; \rho<0,05)$ of colleagues positively affects the loyalty (intension to remain) of the personnel of MFIs in the West region in Cameroon.This result is in line with those of other authors (Dawley et al., 2010; Flint et al., 2013) which globally show that the POS negatively affects the intention to leave. This result obtained in the context of MFIs of the West region of Cameroon can be explained by the fact that the employees attach importance to the social support of colleagues and find it difficult to leave the company and deprive themselves of the social network of which they have built and that is beneficial to them. However, it is shown in the rest of this study that this loyalty determined by the social support is not accompanied by an effective commitment. For this reason, it is very likely that it is only a matter of dependence and not true loyalty. Also, the Cameroonian context is strongly characterised by unemployment (INS, 2011).

4.3.2 Organizational Commitment: The Absence of a Relationship with the Social Emotional Support and Social Professional Support (H2) of Colleagues

Regarding the second hypothesis, we globally reject it. We find that the social emotional support $(\beta=0,194$; insignificant) and the social professional support ( $\beta=-0,004$; insignificant) of colleagues does not have a significant effect on commitment. This result is certainly surprising but can be explained. In fact, the commitment considered is organizational and not related to the work force. Referring ourselves to the predictions of the theory of exchange, the returns of the social support of colleagues is the commitment towards these colleagues and not to the whole organization(Bishop et al., 2005; Stinglhamber and Vandenberghe, 2002). This point of view was recently reiterated by Fabre and Roussel (2013) according to who the LMX leads to alignment with the goals and values of the organization without but this is not the case for TMX which is examined in this study through the social support of colleagues.

\subsubsection{The Negative Effect of Commitment on Loyalty to the Company (H3)}

The first result in this study on the relationship between loyalty and organizational commitment is that commitment negatively affects loyalty $(\beta=-0,613 ; \rho<0,05)$ of the personnel of MFIs in the west region of Cameroon. Hypothesis H3 is thus rejected. This result is also surprising but it should be recalled that the normative commitment and calculated commitment obtained at the end of the factor analyzes have a considerable correlation $(0,490)$ and an absence of discriminating validity. In other words, this means that one of the rules in the commitment consists in the Bamilekés of the MFIs in the West region of Cameroon to be committed in a calculated manner. Unfortunately, these MFIs do not have enough means to meet the 
expectations. This leads to a reduction in the intention to remain in spite of organizational commitment.

This result is in line with that of O'Reilly and Chatman (1986) as well as Campoy and Neveu (2007) who find that calculated commitment is positively correlated with the intention to leave a company and thus contradicts the view of commitment as an indicator of the intention to remain. Moreover, it is shown in the literature that the most committed employees also are stressed (Mathieu and Zajac, 1990) and thus have a great desire to leave (Netemeyer et al., 1995). Moreover, the populations of West Cameroon are characterized by organizational mobility (Warnier, 1993; Fodouop, 1991). In the same manner, Mhiri (2013) shows that the more employees are committed in an emotionally, the more their level of absenteeism and intention to leave increases. These results thus highlight the problem of the optimal degree of commitment which remains unexplored in the literature.

\subsubsection{The Positive Effect of Loyalty on Organizational Commitment (H4)}

The second result obtained on the relationship between loyalty and organizational commitment shows that loyalty (intention to remain) has a positive and significant effect $(\beta=0,845 ; \rho<0,01)$ on the commitment of employees in the MFIs. For this reason, H4 is accepted. In other words, employees originating from the west region of Cameroon have a high organizational mobility (Warnier, 1993; Fodouop, 1991), but are committed since they are loyal. Moreover, as we mentioned earlier, several models of turnover integrate commitment. For this purpose, the policies of development of personnel loyalty also induce their commitment to the company. However, Thevenet (2000) affirms that individuals are not brought to commit themselves but they do so for personal reasons. Following this reasoning, it appears that the intention to remain in a company leads to the organizational commitment of the Bamilékés if they find a profitable opportunity or a means of achieving an experience that would be of future benefit.

\subsection{Contributions of the Study and Managerial Implications}

In order to be coherent, we first present the contributions of the study before the managerial implications.

\subsubsection{Contributions of the Study}

Contrary to the current practice which consists in studying the support of management, this study contributes to the literature on human resource management by examining the relationship between the support of colleagues on loyalty and organizational commitment. Also, this is one of the unusual studies which approach social support of the colleagues in the emotional and professional aspects. For this purpose, it is shown that the effects of these aspects of the social support differ according to whether it is loyalty or organizational commitment. This study shows, contrary with what is usually believed that there is a unidirectional relationship between the intention to remain and commitment to the company. Another main finding is the increase in the intention to leave because of commitment. This result is in line with that of many authors (Campoy and Neveu, 2007; Netemeyer et al., 1995; Mhiri, 2013), and brings us to conclude that commitment is a two-edged sword. Another contribution which is not less important than those above is the absence of discriminating validity between the normative and calculated commitment. On this issue, Solinger et al., (2008) reiterate an old recommendation which consists in returning to a uni-dimensional design. It is thus risky to use a scale without knowing cultural realities in which it was elaborated. There is thus a need for an environmental or contextual approach to measurement scales.

\subsection{Managerial Recommendations}

Given that the social support of colleagues positively affects the loyalty of the personnel to the company without it being the same for commitment to the company; it is desirable for companies that intend to render their personnel committed to increase the social support of colleagues. To do this, they should promote gregarious work which remains unfortunately not implemented in MFIs. However, it should be recalled that this social support is likely to be comparable to a double edged sword because certain employees are likely to mutually support themselves at the point of being vulnerable to the survivor's syndrome. Concerning the effect of loyalty on the commitment of the personnel to the company, it is desirable to reinforce a federating management when organizational commitment is considered. However, the maximization of this commitment should not be an obligation, at the risk of obtaining a boomerang effect on the intention to remain as it is shown in this study and many others (Netemeyer et al., 1995; Mhiri, 2013).

\section{Conclusion}

This study seeks to determine the relationship between the different forms of the social support of colleagues on the loyalty and commitment of the personnel in the MFIs of the West region of Cameroon. We also examine the relationship between loyalty and organizational commitment. The results show that the social support, whatever its nature (social emotional and social professional) positively affects the loyalty of the personnel to the company. This result is well-known in the literature and is in line with those obtained in recent studies (Dawley et al., 2010; 
Flint et al., 2013). This study also reveals that these two aspects of social support do not affect organizational commitment. The reason being that it is mainly about the support of colleagues who, in a logic of exchange lead to a commitment to the employees and not the organization (Bishop et al., 2005; Stinglhamber and Vandenberghe, 2002). We also show that loyalty determines commitment. On the other hand, the more an employee is committed, the more his intention to remain decreases. This result can appear paradoxical but it reveals the famous debate of the degree of commitment. One can thus predict with reference to various other studies (Netemeyer et al., 1995; Mhiri, 2013) that excess commitment is also likely to harm the company. It is thus convenient to explore the mix of commitment as concerns the optimum level and quantity.

Like any empirical study, this study has its limits. The first is related to the spatial limitation of the study. In fact, the study is limited to the West region of Cameroon while a study on the national territory would have revealed more edifying realities. Also, the relationship between the nature of the social support and the work behaviour is not addressed in this study. This is why in future research, we intend to further examine the relationship between the nature of social support and work behaviour by exploring the moderating or moderating role of many other variables.

\section{References}

Abderrahman, J., \& Bernard, F. (2019). L'intention de départ et la performance financière. Une application de la logique floue. Questions de Management, 1(23), 103-116. https://doi.org/10.3917/qdm.191.0103

Allen, N. J., \& Meyer, J. P. (1990). The Measurement and Antecedents of Affective, Continuance and Normative Commitment to the Organization. Journal of Occupational Psychology, 63, 1-18. https://doi.org/10.1111/j.2044-8325.1990.tb00506.x

Allen, N. J., \& Meyer, J. P. (1996). Affective Continuance and Normative Commitment to the Organization: an Examination of Construction Validity. Journal of Vocational Beharvior, 49(3), 252-276. https://doi.org/10.1006/jvbe.1996.0043

Bentein, K., Vandenberg, R., Vandenberghe, C., \& Stinglhamber, F. (2005). The Role of Change in the Relationship Between Commitment and Turnover: a Latent Growth Modeling Approach. Journal of Applied Psychology, 90(3), 468-482. https://doi.org/10.1037/0021-9010.90.3.468

Bishop, J. W., Scott, K. T., Goldsby, M. G., \& Cropenzano, R. (2005). A Construct Validity of Commitment and Perceived Support Variables: A Multifoci Approach Across Different Team Environments. Group and Organization Management, 30(2), 153-180. https://doi.org/10.1177/1059601103255772

Boshoff, C., \& Mels, G. (1995). A causal Model to Evaluate the Relationships Among Supervision, Role Stress, Organizational Commitment and Interna Service Quality. European Journal of Marketing, 29(2), 23-42. https://doi.org/10.1108/0309056951008092

Burke, R. J. (1999). Workaholism in Organizations: Gender Differences. Sex Roles, 41(5/6), 333-345. https://doi.org/10.1023/A:1018818731922

Campoy, E., \& Neveu, V. (2007). Confiance et performance au travail : l'influence de la confiance sur l'implication et la citoyenneté du salarié. Revue Française de Gestion, 33(175), 139-153. https://doi.org/10.3166/rfg.175.139-154

Cerdin, J., \& Peretti, J. M. (2005). La fidélisation des salariés par l'entreprise à la carte. Revue de Gestion des Ressources Humaines, 55, 2-21.

Chen, Z. X., Aryee, S., \& Lee, C. (2005). Test of a mediation model of perceived organizational support. Journal of Vocational Behavior, 66, 457-470. https://doi.org/10.1016/j.jvb.2004.01.001

Colle, R. (2006). L'influence de la GRH à la carte sur la fidélité des salaries: le rôle du sentiment d'auto-détermination, Thèse de Doctorat en sciences de gestion. Université Paul Cezanne, AIX Marseille III.

Cowan, A. P., Farquhar, C., \& MacBride-King, J. L. (2002). Construire aujourd'hui la fonction publique de demain: recruter et maintenir les effectifs, enjeux et solutions, The Conférence Board of Canada.

Cox, T. H., \& Nkomo, S. M. (1991). A Race and Gender-Group Analysis of the Early Career Experience of MBAs. Work and Occupations, 18(4), 431-446. https://doi.org/10.1177/0730888491018004004

Cropanzano, R., Howers, J., Grandey, A., \& Toth, P. (1997). The Relationship of Organizational Politics and Support to Work Behaviors, Attitudes and Stress. Journal of Organization Behavior, 18(2), 159-180. DOI:10.1002/(SICI)1099-1379(199703)18:2<159::AID-JOB795>3.0.CO;2-D 
Dawley, D., Houghton, J. D., \& Bucklew, N. S. (2010). Perceived Organizational Support and Turnover Intention: the Mediating Effect of Personal Sacrifice and Job Fit. The Journal of Social Psychology, 150(3), 238-257. https://doi.org/10.1080/00224540903365463

Deelstra, J. T., Peeters, M. C., Schaufeli, W. B., Stroebe, W., Zijlstra, F. R., \& Van Doornen, L. P. (2003). Receiving Instrumental Support at Work: When Help is Not Welcome, Journal of Applied Psychology, 88, 324-331. https://doi.org/10.1037/0021-9010.88.2.324-31

Dutot, C. (2004). Contribution aux représentations de la fidélité des personnels à l'entreprise : éléments de convergence et de divergence entre ouvriers et employeurs. Le cas des ouvriers de deux industries métallurgiques du pays de Retz, Thèse de Doctorat, Université de Poitiers.

Edwin, A. (2005). Managing Human Resources to Improve Employee Retention. The Health Care Manager, 24(2), 132-149.

Eisenberger, R., Huntington, R., Hutchison, S., \& Sowa, D. (1986). Perceived Organizational Support. Journal of Applied Psychology, 71(3), 500-507.

Fabre, C., \& Roussel, P. (2013). L'influence des relations interpersonnelles sur la socialisation organisationnelle. Revue de Gestion de Ressources Humaines, 84. https://doi.org/10.3917/grhu.087.0003

Flint, G., Haley, L. M., \& McNally, J. J. (2013). The Effect of Employee Perceptions of Monitoring Procedures on Turnover. Problems and Perceptives in Management, 10(3), 75-82.

Fodouop, J. (1991). Les petits métiers de rue et emplois: le cas de Yaoundé. Éditions SOPECAM. Yaoundé.

Gillet, N., Fouquereau, E., Huyhebaert, T., \& Colombat, P. (2016). Effets du soutien organisationnel perçu et des caractéristiques de l'emploi sur l'anxiété au travail et l'épuisement professionnelle : le rôle médiateur de la satisfaction des besoins psychologiques». Psychologique Française, 61, 73-81. https://doi.org/10.1016/j.psfr.2014.05.004

Giraud, L., Roger, A., \& Thomines, S. (2012). La fidélisation des ressources humaines en période de crise économique, Revue de Gestion des Ressources Humaines, 84, 44-60. https://doi.org/10.3017/grhu.084.0044

Griffeth, R. W., Hom, P. W., \& Gaertner, S. (2000). A Meta-Analysis of Antecedents and Correlates of Employee Turnover: Update, Moderator Tests and Research Implications for the Next Millennium. Journal of Management, 26(3), 463-488. https://doi.org/10.1016/S0149-2063(00)00043-x

Grima, F. (2004). Les conséquences de l'ambiguïté de rôle et du conflit de rôle au travail : proposition d'un modèle explicatif synthétique. Revue de Gestion des Ressources Humaines, 54, 56-72.

Hammer, T. H., \& Stern, R. N. (1980). Employee Ownership: Implications for the Organizational Distribution of Power. Academy of Management Journal, 23(1), 78-100. https://doi.org/10.2307/255497

Hom, P. W., Roberson, L., \& Ellis, A. D. (2008). Challenging Conventional Wisdom About who Quitz: Revelation from Corporate America. Journal of Applied Psychology, 93(1), 1-34. https://doi.org/10.1037/0021-9010.93.1.1

Horwitz, F. M., Heng, C. T., \& Quazi, H. A. (2003). Finder, Keepers? Attracting Motivating and Retaining Knowledge Workers. Human Resource Management Journal, 13(4), 23-44. https://doi.org/10.1111/j.1748-8583.2003.t00103

Hulland, J. S. (1999). Use of Partial Least Squares (PLS) in Strategic Management Research: A Review of Four Recent Studies. Strategic Management Journal, 20 195-204. https://doi.org/10.1002/(SICI)1097-0266(199902)20<195::AID-SMJ13>3.0.CO;2-7

INS. (2011). Rapport de la deuxième édition de l'enquête sur l'emploi et le secteur informel. Phase I, INS, Yaoundé.

Kapela, D. T., \& Pohl, S. (2017). Soutien organisationnel, solidarités sociales et engagement des employés: le rôle modérateur de la pauvreté laborieuse. Le travail humain, 80(3), 241-258. https://doi.org/10.3917/th.803.0241

Kapela, D. T., \& Pohl, S. (2019). Les effets du soutien organisationnel, de la qualité de la relation leader-membre et du soutien social sur l'engagement et les comportements de citoyenneté. Politiques psychologiques. https://doi.org/10.1016/j.prps.2018.11.007

Karasek, R. A., \& Theorell, T. (1990). Healthy Work, Stress Productivity and the Reconstruction of Working life. Basic Book, New York. 
Klein, K. (1987). Employee Stock Ownership and Employee Attitudes: a Test of Three Models. Journal of Applied Psychology, 72(2), 319-332. https://doi.org/10.1037/21-9010.72.2.319

Marriot, J. W. (2001). Our Competitive Strength, Vital Speeches of the Day. City News Publishing Co.

Martin, T. N., \& Hafer J. C (1995). The Multiplicative Interaction Effects of Job Involvement and Organizational Commitment on the Turnover Intentions of Full and Part-Time Employees. Journal of Vocational Behavior, 46, 310-331. https://doi.org/10.1006/jvbe.1995.1023

Masterson, S., Lewis, K., Goldman, B., \& Taylor, S. (2000). Integrating Justice and Social Exchange: the Differing Effects of Fair Procedures and Treatment on Work Relationships. Academy of Management Journal, 43(4), 738-748. https://doi.org/10.2037/1556364

Mathieu, J. E., \& Zajac, D. (1990). A Review and Meta-Analysis of the Antecedents Correlates, and Consequences of Organizational Commitment. Psychological Bulletin, 108(2), 171-194. https://doi.org/10.1037//0033-2909.108.2.171

McGinnis, S. K., \& Morrow, C. (1990). Job Attitudes among Full and Part-Time Employees. Journal of Vocational Behavior, 36(1), 82-96. https://doi.org/10.1016/0001-8791(90)90016-U

MEDA. (2007). Responsabilités des fonctions de Gestion des Ressources Humaines dans les moyennes et grande IMF. GRH doc, Portail de micro finance.

Meyer, J. P., \& Allen, N. J. (1991). Three Component Model of Organizational Commitment. Journal of Applied Psychology, 79(1), 15-23. https://doi.org/10.1111/1464-0597.00075

Meyer, J. P., \& Allen, N. J. (1997). Commitment in Work Place: Theory, research and applications, London: Sage Publications. http://dx.doi.org/10/4135/9781452231556

Meyer, J. P., Allen, N. J., \& Smith, C. A. (1993). Commitment to Organization and Occupation: Extension and Test of a Three-Component Conceptualization, Journal of Applied Psychology, 78(4), 538-551. https://doi.org/10.1037/0021-9010.78.4.538

Meyer, J. P., Stanley, D. J., Herzcovitch, L., \& Topolnytsky, L. (2002). Affective Continuance and Normative Commitment to Organization: a Meta Analysis of Antecedent Correlates and Consequences. Journal of Vocational Beharvior, 61, 20-52. https://doi.org/10.1006/jvbe.2001.1842

Mhiri, S. (2013). L'impact du stress professionnel sur l'implication organisationnelle, l'absentéisme et l'intention de quitter chez les cadres. Thèse de Doctorat, Université de Nice Sophia Antipolis.

Mobley, W. H., Griffeth, R., Hand, H. H., \& Meglino, B.M. (1979). Review and Conceptual Analysis of the Employee Turnover Process. Psychology Bulletin, 86(3), 493-522. https://doi.org/10.1037/0037/0033-2909.86.3.493

Mognihan, D. P., \& Landuit, N. (2008). Explaining Turnover Intention in State Government: Examining the Role of Gender, Life Cycle and Loyalty. Review of Public Administration, 28(2), 120- 143.

Mowday, R. T., Steers, R. M., \& Porter, L. M. (1979). The measurement of Organizational Commitment. Journal of Vocational Behavior, 14(3), 224-247. https://doi.org/10.1016/0001-8791(79)90072-1

Mowday, R., Porter, L. W., \& Steers. R. M. (1982). Employee-Organization Linkages: the Psychology of Commitment, Absenteeism and Turn Over. New York: Academic Press. https://doi.org/10.1086/227821

Netemeyer, R. G., Burton, S., \& Johnston, M. W. (1995). A Nested Model Comparison of Four Models of the Consequences of Role Perception Variables. Organizational Behavior and Human Decision Processes, 61, 77-93. https://doi.org/10.1006/obhd.1995.1007

O'Reilly, C., \& Chatman, J. (1986). Organizational Commitment and Psychological Attachment: the Effects of Compliance, Identification, and Internalization on Prosocial Behavior. Journal of Applied Psychology, 71(3), 492-499.

Paille, P. (2002). L'engagement normatif : essai de reconstruction. Psychologie du travail et des organisations, 8(3), 69-96.

Paille, P. (2004). La fidélisation des Ressources Humaines, Collection connaissance de la gestion. Economica, Paris.

Peretti, J. M. (2001). Dictionnaire des Ressources Humaines (2nd ed.).

Perrot, S. (1999). Identification des différentes formes de conflits de rôle: le cas des jeunes diplômés 
nouvellement embauchés.

Perryer, C., Jordan, C., Fims, I., \& Travaglione, A. (2010). Predicting Turnover Intentions: the Interactive Effects of Organizational Commitment and Perceived Organizational Support. Management Research Review, 33(9), 911-923. https://doi.org/10.1108/01409171011070323

Peyrat-Guillard, D. (2002). Les antécédents et les conséquences de l'implication au travail. In Dans J.P. Neveu et M. Thevenet (Eds.), L'implication au travail (pp. 71-96).

Reid, M. E., Allen, M. W., Riemensschneider, C. K., \& Armstrong, D. J. (2008). The Role of Mentoring and Supervisor Support for State IT Employees Affective Organizational Commitment. Review of Public Personnel Administration, 28, 60-78. https://doi.org/10.1177/0275074007303136

Seers, A. (1989). Team-member-exchange quality: A new Construct for Role Making Research. Organizational Behavior and Human Decision Processes, 43, 118-135. https://doi.org/10.1016/0749-5978(89)90060-5

Simons, K. V., \& Jankowski, T. B. (2008). Factors Influencing Nursing Home Social Workers Intentions to Quit Employment, Administration in Social Work, 32, 5-21. https://doi.org/10.1300/J147v32n01_02

Sinclair, R. R., Martin, J. E., \& Michel, R. (1999). Full-Time and Part-Time Subgroup Differences in Job Attitudes and Demographic Characteristics. Journal of Vocational Behavior, 55(3), 337-357. https://doi.org/10.1006/jvbe.1999.1686

Solinger, O., Van olfen, W., \& Roe, R. A. (2008). Beyond the Three Component Model of Organizational Commitment », Journal of Applied Psyvhology, 93, 70-83. https://doi.org/10.1037/0021-9010.93.1.70

Stanley, L., Vandenberghe, C., Vandenberg, R., \& Bentein, K. (2013). Commitment Profiles and Employee Turnover, Journal of Vocational Behavior, 82, 176-187. https://doi.org/10.1016/j.jvb.2013.01.011

Stinglhamber, F., \& Vandenberghe, C. (2002). L'engagement envers l'organisation et le supérieur. Un examen de leurs antécédents. Psychologie du Travail et des Organisations, 8(3), 137-155.

Stinglhamber, F., Bentein, K., \& Vandenberghe, C. (2002). Extension of the Three-Component Model of Commitment to Five Foci: Development of Measures and Substantive Test. European Journal of Psychology Assessment, 18(2), 123-138. https://doi.org/10.1027//1015-5759.18.2.123

Thevenet, M. (1993). La culture d'entreprise. PUF, Paris.

Thevenet, M. (2000). Le plaisir de travailler: favoriser l'implication des personnes. Paris, Editions d'organisation.

Thevenet, M., Dejoux, C., Marbot, E., Normand, E., Bender, A., \& Silva, F. (2012). Fonctions RH: politiques, métiers et outils de ressources humaines (3rd ed.). Pearson Education, Paris.

Tremblay, M., Guay, P., \& Simard, G. (2000). L'engagement organisationnelle et les comportements discrétionnaires: L'influence des pratiques de Gestion des Ressources Humaines. Etude réalisée au CIRANO pour le XI ${ }^{\text {ème }}$ congrès de l'AGRH à Paris, Novembre.

Warnier, J. P. (1993). L'esprit d'entreprise au Cameroun. Collection les Afriques, Karthala, Paris.

Wayne, S. J., Shore, L. M., \& Liden, R. C. (1997). Perceived Organizational Support and Leader-Member Exchange: a Social Exchange Perspective. Academy of Management Journal, 40(1), 82-111. https://doi.org/10.2307/257021

\section{Notes}

Note 1.Peretti (2001) defines a loyal employee as one who has a high seniority in the company (more than 8 years), a very low propensity to search and examine external job offers and a high sense of belonging.

Note 2.This item is more appropriate to capture the loyalty of young employees that cannot be measured by seniority.

\section{Copyrights}

Copyright for this article is retained by the author(s), with first publication rights granted to the journal.

This is an open-access article distributed under the terms and conditions of the Creative Commons Attribution license (http://creativecommons.org/licenses/by/4.0/). 